\title{
Urtzi Etxeberria
}

\section{The partitive marker in Basque, and its relation to bare nouns and the definite article}

This paper aims at making a thorough description of the use of bare nouns, the definite determiner as well as the partitive marker in Basque and its varieties. Concerning the definite article, and assuming that Souletin (the most eastern dialect of Basque) is a previous stage compared to Standard Basque (cf. Michelena 1964, Camino 2017; cf. also Manterola 2012, 2015), the main aim of this paper is to explain how Basque historically moves from a situation where bare nouns are allowed (in some restricted argument position) to a situation where bare nouns are not allowed in argument position. The paper argues that the reason we move from system A to system B is basically due to a semantic weakening and loss of the Souletin null D. In addition, this paper describes the use of the Basque partitive determiner [-(r)ik] (cf. de Rijk 1972, 1996, Etxepare 2003, Etxeberria 2014), its relation with the use of the definite determiner and its evolution from the partitive case marker. Finally, the paper argues that the partitive determiner creates a complex Polarity determiner with a null polarity D.

Note: The research conducing to this paper has benefited from the Netherlands Organisation for Scientific Committee project Partitivity in European Languages (PARTE), the ANR project BIM ANR-17-CE27-11, the Franco-German ANR-DFG project UV2 ANR-18-FRAL-0006, as well as the Spanish MINECO projects INTERCAT FFI2017-82547-P and PGC2018-096380-B-100. I'm very grateful to Giuliana Giusti and Petra Sleeman for inviting me to write this paper, and above all, for their patience throughout the whole process. Thanks also to the audience of the PARTE Workshop in Venice and to the reviewers for this volume for the extensive and helpful comments. Thanks also to Klaus von Heusinger for the careful reading of the paper and for the interesting comments. Finally, thanks also to Ricardo Etxepare, Anastasia Giannakidou, Aritz Irurtzun, and Maia Duguine for helpful comments. Usual disclaimers apply.

Abbreviations used in the glosses: AUX = auxiliary; AUX.SG = singular auxiliary; AUX.PL = plural auxiliary; $A B S=$ absolutive; $A L L=$ allative; $D A T=$ dative; $E R G=$ ergative; $G E N=$ genitive, IN = inessive; INS = instrumental; PART = partitive; SUP = superlative; D.SG = singular definite determiner; $\mathbf{D} . \mathrm{PL}=$ plural definite determiner; $\mathrm{PROG}=$ progressive . 


\section{Introduction}

In this paper, I aim to make a description of the use of bare nouns (henceforth $\mathrm{BNs}$ ), the definite determiner (D), and the partitive determiner in Basque, and to show how these three nominal elements, their use, and their meaning are interconnected and related to each other.

Throughout the paper, I will be making a division, mainly when I talk about the definite determiner, between Souletin, which is the most eastern dialect of Basque, spoken in the area of Zuberoa (a dialect which is considered to be an older version of Basque; cf. Michelena 1964, Camino 2017), ${ }^{1}$ and the rest of the Basque dialects plus Standard Basque. Thus, when I use the term Standard Basque in this paper, I will be making reference to Standard Basque plus the rest of the Basque varieties, except for Souletin. Obviously, by this I do not mean to say that the behaviour of the varieties that I call Standard Basque is parallel in all respects, but when it comes to the use of nominals in argument position, their behaviour appears to be similar (cf. Manterola 2008, 2015).

The paper is organized as follows: in Section 2 I present, (i) the way in which the definite determiner behaves in Standard Basque, where nominals in argument position cannot appear bare, (ii) the behavior of nominals in Souletin, where nominals can appear bare and be arguments but only in direct object position. In line with Etxeberria (2014), I argue that BNs in Souletin project a full DP with an empty D position occupied by a phonetically null D (cf. i.a. Contreras 1986, Longobardi 1994, 2001, Munn \& Schmitt 2005, Cyrino \& Espinal 2014), which provides an indefinite interpretation with narrow scope and is unspecified for number. Then, it is argued that bare nominal expressions in Souletin, and in Basque in general, are unspecified for number or number neutral and their semantic type $\langle e, t\rangle$, i.e. a predicate denoting set. Finally, I argue that the reason why Standard Basque begins to use the definite article [-a(k)] to express an existential interpretation with narrow scope is due to a semantic weakening of the Souletin null D and an eventual loss. This loss forces the overt definite article of Standard Basque - a semantically flexible element (Etxeberria 2005, et seq). - to be used in some positions usually reserved for indefinites. In Section 3, I concentrate on the Basque partitive [-(r)ik] where I first show both its histori-

1 The Basque determiner article historically derived from the distal demonstrative (cf. Azkue 1905, Mitxelena 1979, Irigoien 1981, Azkarate \& Altuna 2001, Etxeberria 2005, Manterola 2012, 2015). Due to space considerations, I will not be addressing the idea that Souletin Basque is an older version of Standard Basque; cf. Michelena (1964), Camino (2017), a.o. for extensive discussion on this. The reader is referred to Manterola $(2012,2015)$, for a historical developmental presentation of the Basque D. 
cal as well as its current uses, from its origin as an ablative, its use as a marker of the range of superlatives or of quantifiers, and a partitive determiner. This is, actually, in line with de Rijk (1972), the evolution that we assume in this paper as correct. Then, it is shown that the partitive determiner, the element on which this article concentrates in, is a super weak Polarity Item (PI) and sensitive to the semantic notion of non-veridicality. Its interpretation in negative contexts is the equivalent of the existential interpretation of the Basque definite article. Finally, taking into account the historical evolution of the partitive, we propose a full DP with a null PI. Section 4 concludes the paper.

\section{Nominals in Standard Basque and Souletin}

\subsection{Nominals and the definite article in Standard Basque}

The Basque D is a bound morpheme that takes the phonetic forms [-a] (when singular) and [-ak] (when plural). ${ }^{2}$
(1) a. mutil-a
boy-D.sG
'the boy'
b. mutil-ak
boy-D.PL
'the boys'

The article appears in the final position of the nominal phrase, attached to the noun as in the example in (1) or attached to an adjective (liburu urdin- $a$ 'lit.: book

2 Some authors argue that the plural form of the Basque D [-ak] is a single element (cf. Goenaga 1980, 1991, Euskaltzaindia 1993, Artiagoitia 1997, 1998, 2002, 2004, 2012, Rodriguez 2003, Trask 2003). Based on Etxeberria (2005, 2010, 2014), I assume that singular and plural markers and the $\mathrm{D}$ are base-generated in different syntactic position, although I will not be providing arguments for it, the reader is referred to Etxeberria (2005, 2010, 2014); see also Eguren (2006). However, for ease of exposition, I will refer to [-a] and [-ak] as the singular and the plural Ds respectively.

Apart from the Basque definite article, the Basque article system also possesses an indefinite article: bat 'one', which is identical to the numeral bat 'one' and probably originated from it (the two can be differentiated through accentuation; when we focus bat the interpretation we get is that of the numeral). Batzuk 'some.pl' is the plural form of the indefinite bat 'one', to which we add the plural marker -zuk. The reader is referred to Etxeberria $(2008,2012,2014)$ for extensive discussion on the article system. See also Trask (2003). 
blue-D; liburu urdin txiki-a 'lit.: book blue small-D'; liburu urdin txiki polit-a 'lit.: book blue small nice-D'). These two properties of the Basque D apply to all dialects. Now, there are some other properties of the use of $D$ in argumental nominal expressions that show dialectal variation.

Initially, we will concentrate on the use of the D in Standard Basque, and then we will move on to Souletin data. As we mentioned in the introduction, it has been assumed (cf. Laka 1993, Artiagoitia 1997, 1998, 2002, 2006, 2012, Etxeberria 2005, 2006, 2010, 2012a, among many others) that BNs cannot be used in argument position in Standard Basque and that the use of the definite article is necessary if sentences are going to be grammatical (the presence of the indefinite article or a weak quantifier also makes the sentence grammatical; due to lack of space we do not provide examples here; cf. Etxeberria 2005, 2008, 2012). This is actually one of the most characteristic properties of the Basque definite article $[-\mathrm{a}(\mathrm{k})]$ in Standard Basque. ${ }^{3}$

(2) Subject position:
a. Lagun ${ }^{\star}(-\mathrm{a})$ berandu etorri zen.
friend-D.SG.ABS late come AUX.SG
'The friend came late'
b. Lagun*(-ak) berandu etorri ziren. lagun-D.PL.ABS late come AUX.PL 'The friends came late'

(3) Direct object position:
a. Amaia-k liburu*(-a) erosi zuen.
'Amaia bought the book'
Amaia.ERG book-D.sG.ABS buy AUX.sG
b. Amaia-k liburu*(-ak) erosi zituen.
Amaia.ERG book-D.PL.ABS buy AUX.PL
'Amaia bought (the) books'

\footnotetext{
3 Basque verbal inflection agrees with the arguments that bear ergative, absolutive and dative case. Thus, the finite verbal form shows different agreement markers for each of the participants of the event expressed by the verb. The auxiliary also agrees with the number (singular or plural) of the participants, see e.g. (2) and (3).

In sentences with transitive verbs, the subject is morphologically marked as ergative and the direct object in the absolutive case (zero suffix). As for one argument-verbs, Basque expresses morphologically a distinction between unaccusative and unergative predicates (Perlmutter 1978; Burzio 1981). Subjects of unergative predicates take the ergative case; subjects of unaccusative predicates, on the other hand, take the absolutive case.
} 
The presence of the definite determiner is also necessary to express the kind reading, as in many other European languages, e.g. Romance languages, or Greek (cf. Kleiber 1990, Krifka et al 1995, Chierchia 1998b, Zamparelli 1998, Fara 2001, Dayal 2004, Borik \& Espinal 2015, Lazaridou et al 2016, et seq., among many others; see also Carlier 2021, this volume, Giusti 2021, this volume).
a. Dinosauru*(-ak) aspaldi desagertu ziren. dinosaur-D.PL.ABS long time ago disappear AUX.PL 'Dinosaurs disappeared a long time ago'
b. Nitrogeno* $(-a)$ ugaria da gure unibertsoan. nitrogen-D.sG.ABS abundant is our universe.IN 'Nitrogen is abundant in our universe'

What is really interesting about the Basque definite article is that when Basque definite DPs (plurals and masses) fill the direct object slot (and only the direct object slot), the definite DP can, but need not make reference to a specific set and can obtain the so-called existential interpretation. In (5), for example, we need not be talking about a specific set of candies or a specific quantity of wine (cf. Section 2.6; cf. also Artiagoitia 1998, 2002, 2006, 2012, Eguren 2012, Etxeberria 2005, 2010, 2014 for alternative (synchronic) analyses).

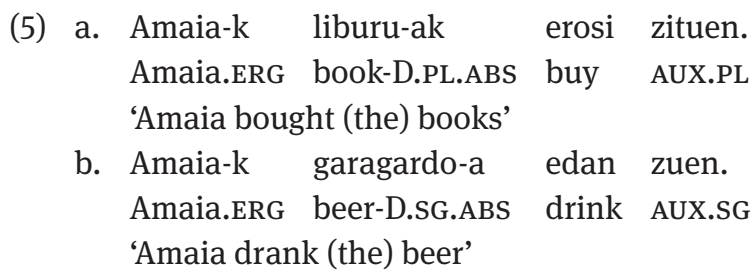

Note that in the examples in (5) the object can also obtain a definite interpretation; so (5a) and (5b) are ambiguous between a referential and an existential interpretation: (5a) 'Amaia bought the books' or 'Amaia bought books'; (5b) 'Amaia drank the beer' or 'Amaia drank beer'. ${ }^{4}$ No kind interpretation is possible.

\footnotetext{
4 Due to space considerations, I will not be considering weak definites at all in this paper. Interestingly, weak definites do exist in Basque, as shown by the example in (i).
(i) Ane-k egunkari-a irakurri zuen.
Ane.ERG newspaper-D.sG.ABS read AUX.SG
'Ane read the newspaper.'

Just note that some properties that weak definites are assumed to have (e.g. habitual or institutionalized activity; stereotypical enrichment; see Carlson \& Sussman 2005, Aguilar-Guevara \&
} 
One may be led to think that the reason why Standard Basque makes use of the definite determiner $[-\mathrm{a}(\mathrm{k})]$ to get the existential interpretation is that it does not have indefinite articles. This is not correct, as Basque possesses singular and plural indefinite articles: bat 'a, one' and batzuk 'some.pl' (cf. Etxeberria 2005, 2008, 2012a for more on this).

It is important to note that the existential interpretation of the object DPs in the examples in (5) has obligatory narrow scope - while the run-of-the-mill indefinites can get both narrow and wide scope - , as is the case with BNs in the object position in English (cf. Carlson 1977; see Dobrovie-Sorin \& Laca 2003, Dobrovie-Sorin 2009, Carlier 2021, this volume, Giusti 2021, this volume, among many others, for Romance). Take the examples in (6).

(6) a. \#Nere aitak bi sator hil zituen ordubetez. my father.ERG two mole.ABS kill AUX.PL hour-for 'My father killed two moles for an hour.'

b. Nere aitak satorr-ak hil zituen ordubetez. my father.ERG mole-D.PL.ABS kill AUX.PL hour-for 'My father killed moles for an hour.'

The sentence in (6a) can only be interpreted with the indefinite bi sator 'two moles' having wide scope over the atelic adverbial ordubetez 'for an hour' and asserts that the same two moles were killed again and again; a rather strange state of affairs. The sentence in (6b), on the other hand, is completely grammatical. The reading we get is one where my father killed different moles and the existentially interpreted definite DP must necessarily take narrow scope below the adverbial ordubetez 'for an hour', i.e. [adv. for > satorrak]. It is true that the DP object of the sentence in (6b) can also get a wide scope reading, but only with the definite reading, and this interpretation would make the sentence as strange as the one in (6a).

In the next section I will concentrate on describing the behavior of nominals (in argument position) and the definite determiner in Souletin.

Zwarts 2010, Aguilar-Guevara 2014, Aguilar-Guevara et al 2014, a.o.) do not apply to the readings the definite article is shown to be obtaining in Basque, $c f$. Section 2. The reader is referred to Etxeberria (in prep.). 


\subsection{The use of the definite article in Souletin}

The definite article of Souletin is a 'well-behaved' definite article; it forces a kindlevel interpretation when combined with kind-level predicates (just like in Standard Basque), and it always forces a referential interpretation in episodic contexts with stage-level predicates.

(7) Subject Position:
a. Lagun- $a$ garaiz iritsi zen.
friend-D.sG.ABS on-time arrive AUX.SG
'The friend arrived on time'
b. Lagun-ak garaiz iritsi ziren.
friend-D.PL.ABS on-time arrive AUX.PL
'The friends arrived on time'

(8) Direct Object Position:
a. Amaiak liburu-a erosi zuen.
Amaia.ERG book-D.sG.ABS buy AUX.sG
'Amaia bought the book.'
b. Amaiak liburu-ak erosi zituen.
Amaia.ERG book-D.PL.ABS buy AUX.PL
'Amaia bought the books.'

The example in $(8 \mathrm{~b})$ is the one that differs from Standard Basque where the definite DP can get both the referential definite reading and the existential interpretation with narrow scope (in (5a)). In Souletin, on the other hand, liburuak can only get the referential meaning, as shown by the translation in (8b). In order to express the kind-meaning, the definite article is obligatory, as was the case in Standard Basque.

\subsection{Existential interpretation: BNs in Souletin}

In order to get the existential interpretation (with narrow scope) Souletin makes use of BNs (only in direct object position; and these BNs can be mass or count), ${ }^{6}$ as

5 The indefinite article (singular and plural) is available also in Souletin and it allows both the wide scope and narrow scope interpretation; $c f$. example (12) below.

6 Mass Ns and count Ns are lexically distinguished in Basque (cf. Etxeberria 2005; $c f$. also Etxeberria in prep). The reader is referred to Etxeberria (2012) for extensive discussion on mass/count Qs. 
shown by the examples in (9) ( $c f$. Txillardegi 1977, Coyos 1999, Casenave-Harigile 2006, Etxebarne 2006, Manterola 2015, Etxeberria 2014). ${ }^{7}$ Recall that BNs cannot be used in argumental position in Standard Basque; see examples (2-4).

Direct Object position:

(9) a. Bortüan ikusi dit behi. mountain.D.SG-IN see AUX.sG cow 'I saw cows in the mountain'

b. Dembora da (...) içan deçadan diru. time is is-have aux money.ABS 'It's time for me to have money' (Bourciez 1895)

c. Zer agitü da? Sagar ebatsi dü. what happen AUX.SG apple steal AUX.SG 'What happened? She/he stole apples'

These BNs get an existential interpretation, which means that the BNs in (9) do not refer to a specific set of whatever the NP denotes; rather, they seem to be non-specific, weak indefinites, like bare plurals of other languages in this position (e.g. English, Spanish). In this paper, we argue that BNs in Souletin are unspecified for number; see Section 2.5.

The fact that BNs in Souletin appear in direct object position and get an existential interpretation suggests that an analysis along the lines of Longobardi (1994, 2001) might be on the right track. Thus, in line with Etxeberria (2012, 2016), the assumptions that I will be making are the following: (i) a null element exists if it alternates - is part of a paradigm - with one or more phonologically realized morphemes and if each element of the paradigm contributes a distinct semantic value; (ii) the DP layer must be projected with a null D (Contreras 1986, Longobardi 1994, 2001, Cyrino \& Espinal 2014, etc.); ${ }^{8}$ (iii) The null D has a default existential interpretation (Longobardi 1994, 2001); (iv) Syntactically, null structure is expected to be subject to licensing conditions (e.g. to appear in object position).

The syntactic structure that these assumptions entail for Souletin BNs is as in (10), a full DP with an empty D head occupied by a phonetically null D.

(10) $\left[{ }_{\mathrm{DP}}[\mathrm{NP}\right.$ behi $\left.\left.\mathrm{N}]-\emptyset \mathrm{D}\right]\right]$

7 BNs cannot be used in subject position; see Section 2.4.

8 Brazilian Portuguese BNs in preverbal position cannot get an existential interpretation, as shown by Cyrino \& Espinal (2014); see also Section 2.5. 
The next subsection provides evidence for this structure by presenting a more complete picture of the behavior of BNs in Souletin.

\subsection{Souletin BNs are syntactically DPs}

One of the predictions of the proposal that Souletin BNs are full DPs with an empty D head is that these BNs will only be able to figure in object positions, not in subject positions. The prediction is borne out.

Subject position:

(11) a. Ergative:
(i) ${ }^{\star}$ Ikasle-k student.ERG
hori
egin dü.
that.ABS
do AUX.SG
(ii) Ikasle-ak
hori egin dü. student-D.sG.ERG that.abs do AUX.SG 'The student did that.'
(iii) Ikasle-ek ${ }^{9}$ hori egin düe. student-D.PL.ERG that.ABS do AUX.PL 'The students did that.'
b. Absolutive:
(i) *Ikasle jin da. student.ABS come AUX.SG
(ii) Ikasle-a jin da. student-D.sG.ABS come AUX.SG 'The student came.'
(iii) Ikasle-ak jin dia. student-D.PL.ABS come AUX.PL 'The students came.'

One other property of Souletin BNs is that they cannot be combined with kindlevel predicates, and the presence of the definite article is necessary in order to be able to refer to the species as a whole (e.g. Lehu*(-ak) desagertzera dia 'Lions are about to disappear'). This is expected: if null D can only get the existential interpretation, no kind reading will be available for Souletin BNs.

9 When the ergative marker attaches to the plural -ak the resulting form is -ek. 
Third, BNs in Souletin cannot refer specifically to the set denoted by the NP, suggesting that they take obligatory narrow scope, again, something expected under the null D proposal. The sentence in (12), for example (where we have the indefinite plural eli bat 'some' in direct object position), is ambiguous between a wide scope reading of the direct object over the verb want where it is possible to refer to the boys denoted by the object NP and a narrow scope reading below the verb want (see von Heusinger \& Kornfilt 2021, this volume). In (12b), the indefinite has narrow scope below want and cannot refer back to the set of boys.

a. some > want

Anek pottiko eli bat nahi dizü ezagutu. Jon, Peru, eta Mikel. Ane.ERG boy some want AUX.sG meet Jon Peru and Mikel 'Ane wants to meet some boys. Jon, Peru and Mikel.'

b. want > some

Anek pottiko eli bat nahi dizü ezagutu. Jon, Peru, eta Mikel. Ane.ERG boy some want AUX.SG meet Jon Peru and Mikel 'Ane wants to meet some boys. Jon, Peru and Mikel.'

The narrow scope reading or the non-specific interpretation of the indefinite in (12b) can also be argued for by a continuation like "but there were no boys", as in (13), where we would show the non-existence of the set of "boys". With such a continuation only the scope relationship in (12b), and by extension, (13b), where the indefinite gets narrow scope below the verb, would be grammatical.

a. some > want

Anek pottiko eli bat nahi dizü ezagutu. \# Baina ez da

Ane.ERG boy some want AUX.sG meet but NEG is

pottikorik inguruan.

boy.PART around.IN

'Ane wants to meet some boys. But there are no boys around.'

b. want $>$ some

Anek pottiko eli bat nahi dizü ezagutu. Baina ez da

Ane.ERG boy some want AUX.SG meet but NEG is pottikorik inguruan.

bOy.PART around.IN

'Ane wants to meet some boys. But there are no boys around.'

In (14), on the other hand, the $\mathrm{BN}$ in object position only gets the narrow scope reading and the continuation is as strange as in (12b) and as grammatical as (13b) in (14a) and (14b) respectively. 
(14) a. Anek pottiko nahi dizü ezagutu. \# Jon, Peru, eta Mikel. Ane.erg boy want Aux.sg meet Jon Peru and Mikel 'Ane wants to meet boys. Jon, Peru and Mikel.'

b. Anek pottiko nahi dizü ezagutu. Baina ez da Ane.ERG boy want AUX.SG meet but NEG is pottikorik inguruan.

boy.PART around.IN

Thus, these BNs are really non-specific, narrow scope indefinites, equivalent to incorporated nominals in languages that would allow incorporation, e.g. Greenlandic Eskimo (van Geenhoven 1998). In Basque, which does not allow noun incorporation (at least in the constructions we are considering here), upon loss of null $\mathrm{D}$, as we will argue to be the case later, the only strategy to salvage the structure is using the next available element, which is the phonologically weak $\mathrm{D}$ [-a]; $c f$. Section 2.6.

Furthermore, the above examples show that Souletin possesses other means to express indefinite/existential readings: zumait 'some' or eli bat 'some' in (12). However, there is a difference between the existential interpretation that these indefinite quantifiers obtain and the one obtained by BNs (see (12), (13), (14)): the latter take obligatory narrow scope, (13-14), in opposition to weak quantifiers, which can get both narrow or wide scope. It is important to recall also that in Souletin the definite article is needed to express both the definite interpretation and the kind interpretation (cf. examples (7), (8)). Thus, the null $\mathrm{D}^{0}$ appears to be part of a paradigm: (i) D [-a(k)]: definite (referential), and kind reading; (ii) bat 'one', zumait 'some', eli bat 'some': indefinite readings with wide/narrow scope; (iii) null $\mathrm{D}^{0}$ : existential reading with narrow scope.

Finally, more evidence in favor of the existence of the null D head in Souletin comes from the possibility of "real" BNs, in languages such as Spanish and other Romance languages (where they have been shown to be real bare nominal expressions, see Espinal 2010, Espinal \& McNally 2011, etc.), to combine with any kind of episodic predicate. These bare nominal expressions, in those languages where they are argued to be really bare, that is, with no null D (as opposed to what we are arguing here for Souletin), are assumed to not be able to combine with predicates of the type break - real episodic predicates - which do not accept as internal arguments elements of type $e, t$ or incorporated type elements (cf. i.a. Espinal \& McNally 2011). In other words, DPs are blocked in incorporation constructions. In fact, when there is an incorporation process, there arise special semantic effects, e.g. the incorporated predicate $(\mathrm{V}+\mathrm{NP})$ designates some typical, characterizing, or generic activity. When incorporating BNs are combined with real episodic predicates the sentence is ungrammatical - or at least pragmatically 
odd. If the nominal expression contains a null $\mathrm{D}$, as we are arguing to be the case in Souletin, no incorporation would be necessary (see above). It follows from here then that Souletin BNs should be able to appear freely as verbal complements and would show no restriction to combine with real episodic predicates of the break type. The prediction is borne out as the example in (15) shows.

(15) Gaur goizeko festan, Peiok godalet hautsi dizü. (Souletin) today morning.GEN party.IN Peio.ERG glass.ABS break AUX.SG 'In the party this morning, Peio broke glasses'

In the next section we will briefly argue for the idea that bare nominal expressions in Souletin, and in Basque in general, are number neutral.

\subsection{Denotation of bare nominal expressions in Basque}

In the existential interpretation of the bare nominal expressions (in object position) in examples such as (9) (repeated as (16)), these bare nominals make non-specific reference to what the noun denotes.

Bortüan ikusi dit behi.
mountain.D-IN see AUX.sG
'I cow.ABS
I saws in the mountain.'

In other words, bare nominal expressions in Souletin, and in Basque in general, are unspecified for number or number neutral (cf. Jespersen 1924, Chierchia 1998a, Corbett 2000, Dayal 2004, Rullman \& You 2006, Wilhelm 2008, Espinal \& McNally 2007, 2011, Krifka et al 1995, Perelstvaig 2013, Görgülü 2018, among many others), that is, a bare nominal expression in Basque can be used to make reference to a singularity or to a plurality, that is, to the whole lattice (not to a kind; or in other words, be compatible with atomic and non-atomic entailments). ${ }^{10}$

As evidence, note that, in Basque (both in Souletin and Standard Basque), numerals combine directly with bare nominal expressions. Thus, in (17a), the phrase ikasle bat 'one student' is semantically singular, while in the example in

10 The property of Basque BNs being number neutral resembles East Asian languages like Mandarin, Cantonese, Thai, etc. where BNs can make reference to singularities or to pluralities. However, despite appearances, there are clear-cut differences between the behavior of Basque BNs and the behavior of the BNs of East Asian languages. The reader is referred to Etxeberria (2014). 
(17b) the phrase hamar ikasle 'ten students' is semantically plural. Yet, the noun ikasle 'student' remains completely uninflected for number in both cases.

(17) Souletin \& Standard Basque
a. ikasle bat
b. hamar ikasle student one ten student 'one student' 'ten students'

Furthermore, in both Souletin and Standard Basque it is possible to use bare nominal expressions as stage-level predicates, denoting a temporary property; and the same nominal, artzain 'shepherd' in (18), can be used to predicate of a singularity or of a plurality.

(18) Souletin \& Standard Basque:

a. Miren artzain joan zen Ameriketara. Miren shepherd go AUX.SG America-to 'Miren went to America (as) shepherd.'

b. Jon eta Miren artzain joan ziren Ameriketara. Jon and Miren shepherd go AUX.PL America-to 'Jon and Miren went to America (as) shepherd(s).'

Finally, in Souletin, bare nominal expressions are also used to express individuallevel predicates (this is not allowed in Standard Basque; see Zabala 1993, 2003, Artiagoitia 1997, 2012, Eguren 2006, 2012; see also Etxeberria in prep), and again, a BN can serve as predicate to both singular subjects such as proper names (19a) and plural subjects such as conjoined NPs (19b). Note that this predicative use of bare nominal expressions is not restricted to capacity nominals ( $c f$. de Swart, Winter, \& Zwarts 2007) since haür 'child' is not a capacity nominal.

(19) Souletin:

a. Miren haür düzü.

Miren child is

'Miren is a child.'

b. Miren eta Peru haür tützü.

Miren and Peru child are

'Miren and Peru are children.' 


\subsection{From Souletin to Standard Basque}

One important assumption that this paper is making is that Souletin is closer to Old Basque than the Standard Basque concerning the nominal system, in line with Manterola (2012, 2015); see also Etxeberria (2014); cf. fn.2. Thus, the question that remains is why/how Standard Basque began to use the D to express the existential interpretation with narrow scope. If bare nominal expressions in Basque are number neutral (see Section 2.4 and Etxeberria 2014) and if in Souletin they are grammatical in internal argument position with an existential interpretation, the use of the Standard Basque D does not appear to be making any semantic contribution in the existential reading since it does not provide any kind of definiteness, ${ }^{11}$ as can be seen in the English translations provided for the sentences in $(20) .^{12}$
Amaia.ERG book-D.PL.ABS buy AUX.SG
'Amaia bought (the) books.'
a. Amaia-k liburu*(-ak) erosi zuen.
b. Amaia-k garagardo-a edan zuen.
Amaia.ERG beer-D.sG.ABS drink AUX.SG
'Amaia drank (the) beer.'

With all this in mind, what motivated Standard Basque to begin to use $[-\mathrm{a}(\mathrm{k})]^{13}$ in order to get the existential reading (with narrow scope), we argue, is twofold: (i) loss of null D, (ii) number morphology.

The null D of the previous stage of Basque, i.e. Souletin dialect, becomes a very weak form semantically as it is non-referential and unspecified for number. This vagueness, i.e. indefiniteness plus number vagueness, eventually dooms this form to loss of its semantic indefinite feature and given that it is a null form, it cannot be reanalyzed and as a consequence it gets lost. The appearance of the overt D in Standard Basque in the indefinite/existential object position, thus, is a kind of reanalysis of the available form D [-a] as a D with existential interpretation (with narrow scope) in these cases. In other words, what I postulate is that the available form $\mathrm{D}$ of Basque is reanalyzed and takes over the function of the indefinite null D ( $c f$. Manterola 2008, 2015, for a possible grammaticisation process - à la Greenberg - of the Basque D). And in fact, this makes sense con-

11 Cf. Etxeberria 2005, 2010 for a different synchronic analysis of the Basque [-a(k)].

12 The objects in (20) can also get the definite interpretation, see (5). I ignore this reading here. 13 [-k] is the plural number marker; $c f$. also Etxeberria $(2005,2010)$. 
sidering that the Basque D [-a] is a phonologically weak element, and as such, it appears to be the first immediate 'proximate' phonologically to the null $\mathrm{D} .{ }^{14}$ As a consequence, Basque can be said to move from the syntactic situation with a null $\mathrm{D}$ to a syntactic situation where the [-a] takes the place of this null $\mathrm{D}$. The need to have the D position filled is syntactic: the loss of null D. Syntactically, the definite article [-a] is always a D, but now it also functions as the overt counterpart of the (otherwise) covert indefinite existential in object position. So in this reading the definite article has a weak function: it applies vacuously, i.e., it is an element of semantic type 〈et,et), Thus, in this case, we have an asymmetry between syntax (need to always have functional structure above the NP in Basque, for an NP to function as an argument), and the semantics, which imposes indefinite meaning.

A second motivation why Standard Basque starts using $[-\mathrm{a}(\mathrm{k})]$ instead of the Souletin null D comes from the fact that Basque begins to mark number morphology explicitly. ${ }^{15}$ In Souletin (and in Standard Basque, see Section 2.5), BNs are number neutral and there is no morphological number on the noun itself as shown by the following example (as is the case in Spanish or in English where plurality is marked by means of [-s]; cf. Delfitto \& Schroten 1991, Bouchard 1998, 2002, Dobrovie-Sorin 2012 for extensive discussion on Number realization and Number interpretation).

(21) Bortüan ikusi dit behi.
mountain-D.IN see AUX.SG cow.ABS
'Lit.: I saw cow in the mountain.'

14 The reason why Basque did not begin to use the indefinite article bat 'a/one' to get the existential reading with narrow scope is probably due to the fact that the indefinite article already has its own indefinite interpretation(s): existential reading with wide and with narrow scope, in opposition to what happens with Souletin BNs and the existential reading of the Standard Basque D, which only get the narrow scope reading.

15 According to some authors, e.g. Irigoien (1985), Manterola (2006, 2012), the reason why Standard Basque begins to mark number explicitly by means of $[-\mathrm{a}(\mathrm{k})]$ is the result of language contact, as the languages around have overt plural markers, e.g. Spanish and French mark plural number on nouns by means of [-s]. This could of course be the case, however, what is left unexplained is why Souletin did not already take the same route and began to mark plural by means of [-ak], because Souletin is also in contact with French. One possibility would be to think that other languages that are in contact with Souletin, e.g. Occitan's variant Gascon, would behave just like Souletin in possessing BNs with no number marker, i.e. no plural marker, and in allowing them only in internal argument position. However, this appears not to be correct, as Occitan and its variant Gascon do have plural morphology [-s]. Thanks to Francesc Roca and Xavier Lamuela for help with Occitan data. 
It is important to emphasize that Basque possesses a plural marker: [-k]. But this plural marker cannot be applied to nouns directly, as the plural marker is a suffix, and as such categorically as well as phonologically dependent on the presence of another category, in this case, the definite article [-a]. So, unless the definite article is present, the plural marker cannot appear in Basque ( $c f$. Etxeberria 2005, 2010 for extensive discussion on where number is interpreted in Basque).

\section{(22) a. *ikasle-k student-PL \\ b. ikasle-a-k student-D.PL}

Thus, in this final section, assuming that Souletin is a previous stage compared to Standard Basque when it comes to the D system (as shown by Manterola 2012, 2015; cf. Michelena 1964, Camino 2017), I have argued that Basque historically derived from a stage where BNs were allowed in internal argument position (i.e. object position) to a stage where BNs in argument position are completely ungrammatical, and the definite article is introduced to express existential interpretation with narrow scope.

In the next section, I will concentrate on the Basque partitive determiner, its relation with the definite determiner, its evolution from the partitive case marker to finally argue that it creates a complex Polarity determiner. Before that, however, I will first concentrate on the partitive case, which is distinguished from the determiner and which is from where it is assumed to have historically derived.

\section{Partitive [-(r)ik]}

\subsection{The partitive case}

The Basque partitive [-(r)ik] was originally named 'negativus' by Oihenart (1638), and it was Lécluse (1826) who began to call it partitive. It is de Rijk $(1972,1996)$ who makes a thorough study of the use of the partitive marker. The partitive attaches to a nominal expression (either count or mass) or to an adjective and it always appears in the final position of the phrase, as is the case with the definite article.

(23) a. mutil-ik 'boy-PART'

b. garagardo-rik 'beer-PART'

c. mutil/garagardo on-ik 'boy/beer good-PART' 

d. mutil txiki on-ik 'boy small good-PART'
e. garagardo hotz on-ik 'beer cold good-PART'

Historically, the partitive case [-(r)ik] is assumed to have originated as an ablative or an elative (see Rijk 1972; see Seržant 2021, this volume for a crosslinguistic survey and a diachronic evolution of the partitive), although nowadays the partitive is not allowed in these constructions.
(24) $[$-rik $]>[$-tik]
Jon Venezia-tik/*-rik dator.
Jon Venezia-ABL come.sG
'Jon comes from Venice.'

However, as a proof of this idea, it is important to note that the partitive functions as an allomorph of the ablative paradigm in Eastern dialects.
(25) a. Eastern dialects: [-tarik] and [-etarik]
Ikasle-eta-rik 'student-D.PL-ABL'
b. Rest of dialects: [-tatik] and [-etatik]
Ikasle-eta-tik 'student-D.PL-ABL'

The partitive case is assumed to be the precursor of the partitive determiner (see de Rijk 1996). However, in the way towards the use of [-(r)ik] as a partitive determiner, it has also been used in three other constructions and contexts: adverbial contexts, superlative constructions, and quantificational contexts (quantifier expressions and PIs) (see Section 3.2.2).

The use of the partitive in adverbial contexts specifies the nature of the action, and it either involves two instances of the same count noun as shown in (26a) or two nouns that denote time as in (26b).

(26) a. ahorik-aho 'from mouth to mouth', etxerik-etxe 'from house to house', mendirik-mendi 'from mountain to mountain', herririk-herri 'from town to town'
b. asterik-aste 'week by week, week after week', urterik-urte 'year by year, year after year'

The partitive [-(r)ik] can also be used to mark the range of the superlative as shown in (27a). Note that the range of superlatives can also be expressed in Basque by a $\mathrm{BN}(27 \mathrm{~b})$ or by the quantificational partitive construction NP-etatik 'of the NP' (27c). 
(27) a. Neska-rik altu-en-a.

girl-PART tall-sUP-D.sG

'the tallest girl'

b. Neska altu-en-a.

girl tall-suP-D.sG

'the tallest girl'

c. Nesk-eta-tik altu-en-a.

girl-D.PL.ABL tall-SUP-D.SG

'the tallest (of the) girls'

In quantificational contexts, the partitive case has been used combined with the nominal expression to mark the range of the quantifier. However, the quantificational use in (28a) is completely lost except for the fossilized eskerrik asko 'thankpart many'. Actually, nowadays, the correct form is necessarily without the partitive case as in (28b) for all cases.
(28) a. ikasle-rik asko
student-PART many
'many students'
b. ikasle asko
student many
'many students'

Finally, the partitive case can also combine with the nominal expression that combines with PI expressions such as inor, ezer, etc. (see de Rijk 1972, Laka 1990, Uribe-Etxebarria 1992, Euskaltzaindia 1993, Etxepare 2003. See also Etxeberria et al 2018, Etxeberria et al 2021 and Espinal et al in prep, who show that these PIs are indefinites), that historically have behaved as quantificational (examples taken from de Rijk 1996).

(29) a. Beretzat ez zegoen beste gizon-ik inor. for her/him NEG AUX other man-PART anybody 'For her/him, there was no other man.'

(Agirre, Kresala, 190)

b. Ez zekien Liberen bihotz-barrengorik ezer.

NEG AUX Libe-gen heart-inside-PART anything 'S/he knew nothing of what was inside Libe's heart.' (Agirre, Uztaro, 114) 
From all the above-mentioned uses of the partitive case, only the adverbial and the superlative uses are nowadays active, the two quantificational uses (partitive combined with Q expressions such as asko and partitive combined with NPIs) are lost. In the next subsection I will concentrate on the partitive determiner, which, I assume, in line with de Rijk $(1972,1996)$, evolved from the partitive case passing by a process when it functioned as the marker of the range of quantifiers. Finally, in Section 3.3 I will propose an analysis of the partitive determiner in terms of a null Polarity determiner.

\subsection{The partitive determiner}

Many authors have treated the partitive [-(r)ik] as an article (Larramendi 1729; Azkue 1905, 1923 among others; see de Rijk 1972 for historical references). If this is really the case (and it is true that syntactically it behaves as an article) the partitive must be a special kind of an article since it does not accept overt case markers (in opposition to what happens with any other Basque article, e.g. the definite article). This impossibility may be related to the fact that the partitive determiner derived, as we assume to be the case, from a case marker. In this paper, we will use the term 'partitive' to refer to the particle [-(r)ik] (in line with other traditional grammars; see Lafitte 1944).

(30) a. Absolutive case:

(i) Mutil-a- $\varnothing$ boy-D.sG-ABS

(ii) Mutil-ik- $\varnothing$ bOy-PART-ABS

b. Ergative case:

(i) Mutil-a-k boy-D.sG-ERG

(ii) ${ }^{\star}$ Mutil-ik-(a)k bOy-PART-ERG

c. Dative case:

(i) Mutil-a-ri boy-D.sG-DAT

(ii) *Mutil-ik-(a)ri bOy-PART-DAT

The fact that the partitive can only appear with absolutive case explains the fact that only attaches to transitive direct objects (31) and to intransitive subjects (32). 
(31) a. Kepak ez du baloi-rik ekarri. Kepa.ERG NEG AUX ball-PART bring 'Kepa has not brought any ball.'

b. Anek ez du garagardo-rik edan. Ane.ERG NEG AUX beer-PART drink 'Ane has not drunk beer.'

(32) a. Mendian ez da hildako animalia-rik azaldu. mountain-IN NEG AUX dead animal-PART appear 'No dead animal appeared in the mountain.'

b. Bilerara ez da irakasle-rik etorri. meeting-to NEG AUX teacher-PART come 'No teacher has come to the meeting.'

Obviously, since the partitive can only take absolutive case it cannot be used as subject of transitive sentences which in Basque require the subject to appear with the ergative case, something that partitives cannot do (see (30b)).

(33) a. *Katu-rik sagua jan du. cat-PART mouse eat AUX

b. ^Katu-rik ez du sagua jan. cat-PART NEG AUX mouse eat

One interesting property of the partitive determiner is that it behaves as a "polarity element" in that it only appears in polarity contexts. Thus, as expected, it can appear in negative contexts, as in the previous examples (31-32), and as shown by the following example. ${ }^{16}$

(34) a. Ane-k ez du garagardo-rik edan. Ane.ERG NEG AUX beer-PART drink Ane did not drink any beer.

b. ${ }^{\star}$ Ane-k garagardo-rik edan du. Ane.ERG beer-PART drink AUX

16 Note that the sentence in (33a) is ungrammatical for two reasons: (i) the subject is not marked with ergative case, and (ii) the sentence is not negative. The presence of negation does not improve the sentence by itself, as shown by (33b). 
Apart from negative contexts, some other syntactic environments allowing the partitive are the following (cf. de Rijk 1972, 1996; Trask 2003; Etxepare 2003 for a complete description): (i) existential sentences (35a); (ii) yes/no questions (35b); (iii) protasis of conditional (35c); (iv) before clauses (35d); (v) without clauses (35e); (vii) epistemic modals (35f).

(35) a. Bada turista-rik Donostian! $!^{17}$ yes-is tourist-PART Donostia-IN 'There are (lots of) tourists in Donostia!'

b. Goxoki-rik nahi al duzu? candy-PART want QUEST AUX 'Do you want any candy?'

c. Istilu-rik badago, ospa egin riot-PART if.AUX flee do 'If there are any riots, get out.'

d. Zozo keria-rik egin baino lehen, goazen. hemendik silly thing-PART do than before let-go here-from 'Go home before you do silly things.'

e. Diru-rik gabe atera naiz etxetik. money-PART without leave AUX home-from 'I left home without money.'

f. Beharbada entzungo dut albiste on-ik. perhaps hear.FUT AUX new good-PART 'Perhaps I will hear good news.

The examples above come to show that the partitive [-(r)ik] is licensed by an anti-morphic operator, e.g., by sentential negation, (31-32-34-35). Partitive [-(r)ik] can also be licensed in anti-additive contexts such as the restriction of the universal quantifier guzti 'all' (36), as well as in downward entailing contexts such as the scope of the weak quantifier gutxi 'few, little', (37a), or the scope of affective predicates such as zalantza egin 'doubt', (37b). Finally, partitive [-(r)ik] can also occur in non-veridical contexts, such as the protasis of a conditional, (35c).

17 Constructions such as those in (35a) are only possible as an exclamation; see de Rijk (1972, 1996). The interpretation of these kinds of sentences is parallel to bada atzerritar asko 'there are many foreigners'; see example (28). If we add an adjective to the noun, the sentence needs not be an exclamation: ardo onik badute taberna honetan 'they have good wine in this bar', gizon onik bada Euskal Herrian 'there are good men in the Basque Country' (cf. de Rijk 1972: 178; cf. also $30^{\text {th }}$ law of the Academy of the Basque Language, Euskaltzaindia). These cases will not be considered in this paper. 
(36) Historia libururik irakurri duten ikasle guztiek Frantses iraultza History book.PART read AUX student all-D.PL French revolution ezagutu behar dute.

know must AUX

'Every student who has read any history book must know the French revolution.'

(37) a. Ikasle gutxik irakurri dute libururik. ${ }^{18}$ student few.ERG read AUX book.PART 'Few students read any book.'

b. Zalantza egiten dut Anek libururik irakurri duen. doubt do.IMPF AUX Ane.ERg book.PART read AUX.COMP 'I doubt that Ane read any book.'

This comes to show that the contexts in which the partitive [-(r)ik] appears and the behaviour that it shows are parallel, except for the existential contexts, to the inor, ezer type of PI (See Etxeberria et al 2018, Etxeberria et al submitted and Espinal et al in prep).

According to Hoeksema (2012)'s Extended Zwarts' hierarchy for PIs (combining Zwart's 1981 and van der Wouden's 1994 classification; that we offer in (38)) the partitive [-(r)ik] would qualify as a superweak PI. In other words, the partitive [-(r)ik] is licensed in the contexts expressed by the most external of the concentric circles in (38).

18 The downward entailing quantifier gutxi 'few' behaves like focus operators in that it induces a change in the basic word order of the clause (cf. Etxepare 2003; Etxeberria 2005, 2008, 2012, in prep). Focus phrases in Basque must appear in the immediately preverbal position, which produces a change in the basic SOV Basque word order (cf. a.o. Eguzkitza 1986, Ortiz de Urbina 1983, 1989, 1999, Uriagereka 1999, Arregi 2003, Irurtzun 2006, 2016).

(i) a. $*[\text { Peru-k }]_{\mathrm{F}}$ baloi-a zulatu du. Peru.ERg ball-D.sG.ABS burst AUX.SG 'Peru has burst the ball.'

b. Baloia [Peruk $]_{F}$ zulatu du.

c. $\quad[\text { Peruk }]_{F}$ zulatu du baloia.

This is exactly what happens with gutxi in (37a), i.e., it must necessarily occupy the preverbal (focus) position, as the ungrammaticality of the example in (ii) shows.

(ii) `Ikasle gutxi-k ezer ikusi dute. student few.ERG anything.ABS see AUX 


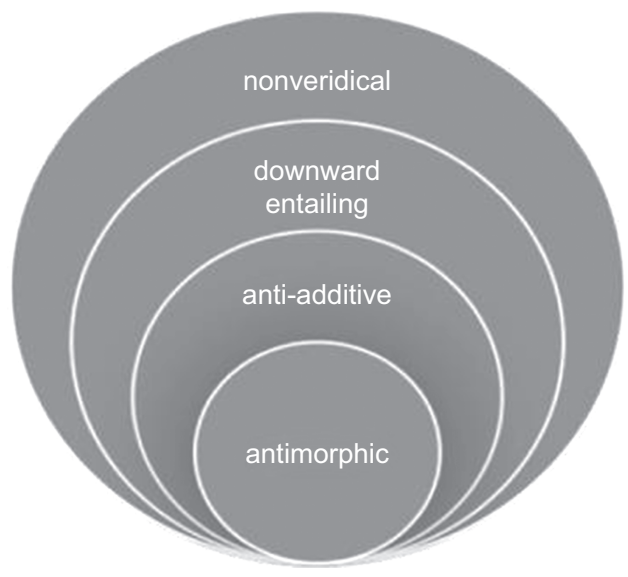

(38) Hoeksema (2012, p. 4): Extended Zwart's Hierarchy

Thus, what all the examples above show is that the partitive [-(r)ik] is sensitive to the semantic notion of (non-)veridicality (Zwarts 1995, 1998; Giannakidou 1997 et seq.; Hoeksema 2012; etc.).

A veridical context is one that allows the speaker to infer the truth of a sentence, that is, veridicality is a property of sentence embedding functions: a function $F$ is veridical if $F(p)$ entails or presupposes the truth of $p$. Thus, for example, an adverb like unfortunately in a sentence like Unfortunately, Mary saw a snake is veridical in that Mary saw a snake is true. A non-veridical context, on the other hand, is one where the truth inference seems to be suspended (e.g. modal adverbs like possibly or maybe). Non-veridicality, which is defined in (39), introduces a function $F$ that can be expressed by means of negation (an anti-veridical operator), polar questions, before-clauses, downward entailing quantifiers, and conditionals, among others.

(39) Non-veridicality

A function $F$ is non-veridical if and only if $F(p)$ does not entail $p$. (Giannakidou 1997)

Observing all the examples that we have provided, a clarification is in order here concerning the example in (35a), repeated here for convenience, where partitive [-(r)ik] appears inside an existential sentence.

(35a) Bada turista-rik Donostian! yes-is tourist-PART Donostia-IN 'There are (lots of) tourists in Donostia!' 
To begin with, this kind of existential sentences are only grammatical if they are exclamatives, and exclamatives have been argued to be non-veridical contexts in the literature (see Giannakidou 1998: p.131). However, as we just mentioned, considering that exclamatives are non-veridical contexts, and that the partitive [-(r) $\mathrm{ik}$ ] is a PI, we would expect turistarik in (35a) to be interpreted as a PI, but it is not, as its interpretation is not 'any tourist' but as 'lots of tourists' (see footnote 18). If this is the case, this construction would appear to be a remnant of the quantificational constructions that we presented in Section 3.1 (example 28), i.e. ikasle-rik asko 'many students', because there is nothing in the construction that could be providing the 'many, lot of' meaning. Thus, existential sentences, at least in what concerns the use of the partitive determiner in Basque, need not be considered as licensors of the polar interpretation of the partitive [-(r)ik] for the reasons that I just mentioned.

\subsubsection{The interpretation of the partitive determiner}

The partitive [-(r)ik] can be argued to be the negative equivalent of the existential interpretation (in absolutive case) of the Basque definite article [-a(k)] (see de Rijk 1972, Irigoien 1985, Etxeberria 2014). Before I proceed, let me make a clarification note on de Rijk (1972: 140): de Rijk argues that the English translation of the Basque sentence in (40a) is (40b)-but see the glosses. He proposes (40c) as the correct negative form of the sentence (40a); (40d) on the other, would not be the correct negative form of (40a) since the article [-a] would only get a definite interpretation.

(40) a. Ijito-a ikusi degu.

(de Rijk 1972: (6a))

gipsy-D.sG see AUX

'We have seen the gipsy.'

b. We have seen a gipsy.

(de Rijk 1972: (6a))

c. Ez degu ijito-rik ikusi. (de Rijk 1972: (7a))

NEG AUX gipsy-PART see

'We have not seen any gipsy.'

d. Ez degu ijito-a ikusi.

(de Rijk 1972: (8a))

NEG AUX gipsy-D.sG see

'We have not seen the gipsy.'

The singular definite article [-a] can only be interpreted existentially in very specific contexts (so-called stereotypical contexts, which are clearly related to possession; see Etxeberria 2005, 2012, 2014) and the example in (40a) is not such a 
context. As a consequence, if we would translate the sentence in (40a) we would be forced to use the definite determiner due to the fact that the only possible interpretation of ijitoa 'gipsy-D.sg' in (40a) is definite and specific. Thus, the correct English translation is the one we have in the glosses, i.e. we have seen the gipsy (and not the one in (40b), for which Basque has a perfect counterpart: ijito bat ikusi dugu 'lit.: gipsy one see Aux'). And the negative form of (40a) would be (40d); in both cases we are making reference to a specific gipsy.

Then, it is clear from the examples above that it is impossible to use the partitive [-(r)ik] as the negative form of elements that force a definite and specific reading (as is the case with the article [-a] when combined with count terms; see Etxeberria 2005, 2008, 2014). In fact, we get exactly the same effect with the plural version of the definite article [-ak] in (41a): if the sequence [ikasle-ak] is interpreted as definite and specific, its negative form will also make use of the definite article [-ak] (41b). However, if the sequence [ikasle- $a k$ ] is interpreted existentially (remember that this interpretation is only allowed in direct object position; see Section 2.1), its negative form will make use of the partitive [-(r)ik], as shown in (41c).

(41) a. Izarok ikasle-ak ikusi ditu.

Izaro.ERG student-D.PL.ABS see AUX.PL

'Izaro saw (the) students.'

$[\sqrt{ }$ definite $/ \sqrt{ }$ existential $]$

b. Izarok ez ditu ikasle-ak ikusi.

Izaro.ERG NEG AUX.PL student-D.PL.ABS see

'Izaro did not see the students.'

[ $\sqrt{ }$ definite $/$ * existential]

c. Izarok ez du ikasle-rik ikusi.

Izaro.ERG NEG AUX.SG student-PART see

'Izaro did not see (any) students.'

[* definite / $\sqrt{ }$ existential]

We would observe exactly the same behaviour if we used the definite article [-a] with mass terms. Thus, the sentence in (42a) is ambiguous between a definite and an existential interpretation of the direct object: in the definite interpretation, we would be talking about a specific cognac, e.g., one that has been mentioned before in the conversation; in the existential interpretation on the other hand, we would not be talking neither about a specific cognac nor about a specific quantity of cognac. The negative form of the definite interpretation is the one in (42b), whereas the negative form of the existential interpretation will make use of the 
partitive form [-(r)ik] as in (42c) (see Huumo 2021, this volume for the unbounded interpretation of the Finnish partitive).

a. Izarok ardo-a edan du.

Izaro.ERG wine-D.SG.ABS drink AUX.SG

'Izaro drank (the) wine.'

$[\sqrt{ }$ definite $/ \sqrt{ }$ existential $]$

b. Izarok ez du ardo-a edan.

Izaro.ERG NEG AUX.SG wine-D.SG.ABS drink

'Izaro didn't drink the wine.'

[ $\sqrt{\text { definite } / *}$ existential]

c. Izarok ez du ardo-rik edan.

Izaro.ERG NEG AUX.SG wine-PART drink

'Izaro didn't drink the wine.'

[^ definite / $\sqrt{ }$ existential]

Note that in Souletin, the partitive would be used as the counterpart of the BN in object position, which can only obtain an existential interpretation (see Section 2.3).

Interestingly, just as was the case with the existential interpretation of the definite article in Standard Basque and the BNs in Souletin, partitive [-(r)ik] can only get narrow scope interpretation when combined with sentential negation, for example, as shown by the example in (43a) (see Giusti \& Sleeman 2021, this volume). This narrow scope interpretation is not an option for the run-of-the-mill indefinite article bat, which resists being interpreted below negation, (43b). It is neither a possibility for the anti-specific, referentially vague indefinite -ren bat 'lit.: genitive one' which cannot appear combined with negation and results in ungrammaticality, (43c) (see Haspelmath 1997, Giannakidou 1997, 2001, Kratzer \& Shimoyama 2002, von Fintel 2000, Alonso-Ovalle \& Menéndez-Benito 2010, 2011, Giannakidou \& Quer 2013, Giannakidou \& Yoon 2016, etc.; see Etxeberria in prep., for Basque).

(43) a. Anek ez du goxokirik jan.

Ane.ERG NEG AUX.SG candy-PART eat

'Ane didn't eat any candy.'

[ $\sqrt{ }$ NEG $>$-RIK / * -RIK > NEG]

b. Anek ez du goxoki bat jan.

Ane.ERG NEG AUX.sG candy one eat

'Ane didn't eat a candy.'

[\# NEG > BAT / V BAT > NEG] 
c. *Anek ez du goxoki-ren bat jan.

Ane.ERG NEG AUX.SG candy.GEN one eat

'Ane didn’t eat some candy (or other).'

$\left[{ }^{\star} \mathrm{NEG}>\mathrm{BAT} /\right.$ * $\left.\mathrm{BAT}>\mathrm{NEG}\right]$

This could be the result of a blocking effect: since negation triggers an NPI interpretation, any other indefinite under negation is a marked, and therefore, a dispreferred option.

Finally, note that, as expected, the interpretation of the partitive [-(r)ik] is non-specific, in the sense that the speaker cannot have a specific set in mind (see von Heusinger \& Kornflit 2021, this volume).

(44) Anek ez du lagun-ik ikusi. *Jon eta Miren ziren. Ane.ERG NEG AUX.SG friend-PART see Jon and Miren be.PL 'Ane didn't see any friend. They were Jon and Miren.'

Summarizing, the properties of the Basque partitive [-(r)ik] in general are the following: (i) it behaves as an anti-specific and narrow scope indefinite that furthermore needs to appear and be licensed in non-veridical contexts; (ii) it is used as the negative form of the existential interpretation of the Basque definite article (or Souletin BNs); (iii) it makes reference to an unspecified quantity of what the nominal expression denotes, which is related to the fact that BNs in Basque are unspecified for number or number neutral. In other words, what the speaker aims at expressing when using a $\mathrm{N}$ combined with the partitive in a negative context is that there are no elements from the set denoted by the NP.

\subsubsection{Historical evolution of the partitive determiner}

Historically, and in line with de Rijk (1996), I assume that the Basque partitive determiner [-(r)ik] follows the process where it is created as the ablative or the elative case (as suggested in Section 3.1), so as a case marker: [-rik] > [-tik]. Jon Venezia-tik dator 'Jon comes from Venice' (see Seržant 2021, this volume, for a diachronic analysis of the partitive from a crosslinguistic perspective; see also Carlier 2021, this volume).

As we said, this would explain the presence of the partitive as an allomorph of the ablative paradigm in Eastern dialects as in ikasle-eta-rik 'student-D.pl-abl' in opposition to what happens in the rest of the variants ikasle-eta-tik 'student-D. pl-abl'. 
In a second step, it would behave as the range of some quantifiers, such as asko 'many, much' or PIs of the type inor 'anybody', ezer 'anything', uses that are lost and not productive anymore. Finally, in a third step, it starts behaving as an indefinite, a non-specific PI with narrow scope.

\section{(45) Partitive case > Range of Quantifiers > Partitive article}

Carlier (2007) argues that in French there is a development of a partitive article from the partitive construction that brings a meaning shift and which developed in Middle-French. The reader is referred to Carlier (2007) for more specifics about her proposal and analysis (see also Carlier 2021, this volume). What interests us here is the conceptual shift from partition to indefiniteness that she argues has existed in French as well as in other Indo-European languages with case inflection (e.g. Russian, see Timberlake 1977, Paykin \& van Peteghem 2002, or Finnish, see Laasko 2001, Karlsson 1983; see also Carlier 2021, this volume). This partitive article expresses indefiniteness and non-limited quantity, that is, it makes quantitatively unspecified reference. In the end, this is also the case for the Basque partitive [-(r)ik], as we argued above concerning its number neutrality.

\subsection{The partitive determiner: Null Polarity D}

The syntactic structure that I propose for a construction where we combine a nominal expression with the partitive determiner [-(r)ik] is the one expressed in (46).

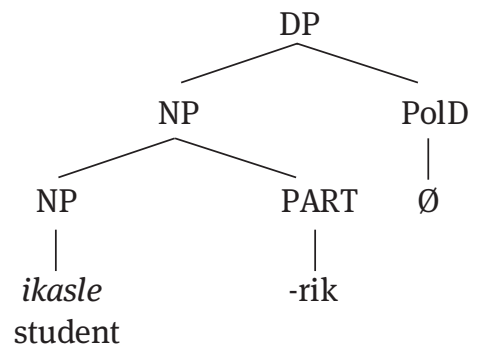

Assuming this structure as correct comes to say that the partitive [-(r)ik] behaves as a modifier in the sense that it does not change the type of the nominal expression, i.e. it takes an element of type $\langle e, t\rangle$ and gives back an element of the same type $\langle e, t\rangle$, so it is an element of type $\langle e t, e t\rangle$. Therefore, what I will argue is that the partitive does not add much except for the fact that it expresses the need of 
polarity (or non-veridicality). This structure reminds us of the structure we would be proposing for the Souletin BNs in object position.

The reason why I put forward the structure in (46) for a construction like [NP-(r)ik] comes from the fact that historically, as I argued in the previous subsection and as already argued by de Rijk (1996), the partitive [-(r)ik] evolved from the ablative case marker that in an in between step marked the range of quantificational elements of the type inor/ezer which are themselves nowadays PIs (see de Rijk 1972, de Rijk 1996, Laka 1990, Uribe-Etxebarria 1992, Euskaltzaindia 1993, Etxepare 2003; see also Etxeberria et al. 2018, Etxeberria et al. submitted, and Espinal et al., in prep), as shown by the example in (29), repeated here for convenience as (47). It is important to keep in mind that the structures that we offer in (47), i.e. gizonik inor 'any man' and bihotz-barrengorik ezer 'any guts/intrails' are ungrammatical nowadays.

a. Beretzat ez zegoen beste gizon-ik inor. for her/him NEG AUX other man-PART anybody

For her/him, there was no other man.

(Agirre, Kresala, 190)

b. Ez zekien Liberen bihotz-barrengorik ezer.

NEG AUX Libe-GEN heart-inside-PART anything

S/he knew nothing of what was inside Libe's heart.

(Agirre, Uztaro, 114)

From these kinds of constructions, we evolve towards the partitive article by eliminating the quantificational inor/ezer from the structure, which become to be used as pronominal indefinites. Thus, what the Null Polarity Determiner does is take the place of these PIs and the partitive becomes a PI itself.

In line with Giannakidou (1998 et seq.) we assume PIs to introduce a dependent variable. Giannakidou (1998 et seq.) and Giannakidou \& Quer (2013) propose that NPIs may contain a dependent variable and Greek, Mandarin, and Korean NPIs have been argued to belong to this class. As a consequence, the dependent character of NPIs becomes part of the elements that show referential 'deficiencies' like, for instance, anaphoric nominals, anti-specific and obligatorily narrow scope indefinites, English bare plurals (Carlson 1977), distributivity markers (Farkas 1998, Pereltsvaig 2008, Henderson 2014), etc.

(48) Dependent variables of NPIs (Giannakidou 2011)

An existential quantifier $\exists x_{d}$ is dependent iff the variable $x_{d}$ it contributes does not introduce a discourse referent in the main context. 
Thus, a dependent variable (i) is lexically dependent and as a consequence has limited distribution, (ii) cannot introduce a discourse referent in the actual world, (iii) is unable to get a value from the context and will always take narrow scope, and (iv) its distribution is constrained in contexts where there is an operator it can be bound by.

The Basque partitive [-(r)ik] then, will be taken to introduce a dependent variable that is licensed in non-veridical contexts, as it has been shown in Section 3.2.

\section{Final remarks}

In the first part of the paper, assuming that Souletin is a previous stage compared to Standard Basque when it comes to the D system (as shown by Manterola 2012, 2015), it has been argued that Basque historically derived from a stage where BNs were allowed in internal argument position (i.e. object position) to a stage where BNs in argument position are completely ungrammatical, and the definite article is introduced to express existential interpretation with narrow scope. In support of this analysis, the paper first made a thorough description of the use of BNs, and of the use of the definite article in both Souletin (the most eastern dialect of Basque) and in Standard Basque (plus all the rest of the dialects). I also argued that in Souletin, BNs are full DPs with an empty head occupied by a phonetically null D - with indefinite reference and unspecified for number -, partly in line with Longobardi (1994, 2001).

I have argued that the reason we move from a system like Souletin to a system where BNs are not allowed, i.e. Standard Basque, is basically due to a semantic weakening and loss of the null D: (i) in Souletin BNs are full DPs with an empty head occupied by a phonetically null $\mathrm{D}$ - with indefinite reference and unspecified for number-; (ii) this null D loses its semantic features and since it is null it cannot be reanalysed and gets lost; (iii) in Standard Basque the definite article $[-\mathrm{a}]$ is reanalysed and takes the place of the null $\mathrm{D}$ and begins to acquire the function of the lost null D.

In the second part of the paper, I have concentrated on the partitive [-(r)ik], where I have assumed, in line with de Rijk (1996), that the partitive determiner evolved from the partitive case passing by a process when it functioned as the marker of the range of quantifiers. Taking into account the Extended Zwarts' hierarchy as proposed by Hoeksema (2012), I have shown that the partitive determiner is licensed in non-veridical contexts and that it is a superweak PI. Furthermore, the partitive [-(r)ik] has been shown to be the negative form of the existential interpretation of the Basque definite article [-a(k)] (or BNs in Souletin), 
an anti-specific indefinite that always takes narrow scope. Syntactically, I have proposed the existence of a Null Polarity Determiner that introduces a dependent variable that needs to be bound.

\section{References}

Agirre, Txomin. 1906. Kresala. Durango: Florentino Elosu-ren echean.

Agirre, Tomas. 1937. Uztaro. Bilbao: Editorial Vasca.

Ana Aguilar-Guevara. 2014. Weak definites: semantics, lexicon, and pragmatics. Utrecht: LOT. Aguilar-Guevara, Ana, Bert Le Bruyn \& Joost Zwarts (eds). 2014. Weak referentiality (Linguistics Today 219). Amsterdam: John Benjamins.

Alonso-Ovalle, Luis \& Paula Menéndez-Benito. 2010. Modal indefinites. Natural Language Semantics 18(1). 1-31.

Alonso-Ovalle, Luis \& Paula Menéndez-Benito. 2011. Domain restriction, modal implicatures and plurality: Spanish ‘algunos'. Journal of Semantics 28(2). 211-240.

Arregi, Karlos. 2003. Focus on Basque movements. Cambridge, MA: MIT dissertation.

Artiagoitia, Xabier. 1997. DP predicates in Basque. In Maria Galvão (ed.), University of Washington Working Papers on Linguistics 15 (UWWPL), 161-198.

Artiagoitia, Xabier. 1998. Determinatzaile Sintagmaren Hipotesia Euskal Gramatikan. Uztaro 27. 33-61.

Artiagoitia, Xabier. 2002. The functional structure of Basque noun phrases. In Xabier Artiagoitia Patxi Goenaga \& Joseba Andoni Lakarra (eds.), Erramu Boneta: Festschrift for Rudolf P. G. de Rijk, 73-90. Bilbao: University of the Basque Country.

Artiagoitia, Xabier. 2004. Izen-Sintagmaren birziklatzea: IS-tik izenaren inguruko funtzioburuetara. In Pablo Albizu \& Beatriz Fernandez (eds.), Euskal Gramatika XXI Mendearen Atarian: Arazo Zaharrak, Azterbide Berriak, 13-38, Vitoria-Gasteis: UPV/EHU.

Artiagoitia, Xabier. 2006. Euskarazko izen sintagma: arkitektura eta egitura funtzionala. Unpublished manuscript, UPV/EHU.

Artiagoitia, Xabier. 2004. Izen-Sintagmaren birziklatzea: IS-tik izenaren inguruko funtzioburuetara. In Pablo Albizu \& Beatríz Fernández (eds.), Euskal Gramatika XXI Mendearen Atarian, 13-38. Gasteiz: EHU-Arabako Foru Aldundia.

Artiagoitia, Xabier. 2012. The DP hypothesis in the grammar of Basque. In Urtzi Etxeberria, Ricardo Etxepare \& Myriam Uribe-Etxebarria (eds.), Noun phrases and nominalization in Basque: Syntax and semantics, 21-78, Amsterdam: John Benjamins.

Azkue, Resurreción María. 1905. Diccionario vasco-español-francés. Bilbao: La Gran Enciclopedia Vasca.

Azkue, Resurreción María. 1923. Morfologia Vasca, Bilbao: La Gran Enciclopedia Vasca. [Edizio berria: 1969]

Borik, Olga \& M. Teresa Espinal. 2015. Reference to kinds and to other generic expressions in Spanish: Definiteness and number. The Linguistic Review 32(2). 167-225.

Bouchard, Denis. 1998. The distribution and interpretation of adjectives in French: a consequence of bare phrase structure. Probus 10. 139-183.

Bouchard, Denis. 2002. Adjectives, number and interfaces. Why languages vary. Amsterdam: Elsevier. 
Burzio, Luigi. 1981. Intransitive verbs and Italian auxiliaries. Cambridge, MA: MIT dissertation.

Camino, I. 2011 [2014]. Ekialdeko euskararen iraganaz. In Irantzu Epelde (ed.), Euskal dialektologia: lehena eta oraina (Supplements of the International Journal of Basque Linguistics and Philology [ASJU] 69), 87-153. Bilbao: University of the Basque Country.

Carlier, Anne. 2007. From preposition to article: The grammaticalization of the French partitive. Studies in Language 31(1). 1-49.

Carlier, Anne. 2021, this volume. Du/Des NPs in French: a comparison with bare nouns in English and Spanish. In Petra Sleeman \& Giuliana Giusti (eds.) Partitive determiners, partitive pronouns and partitive case. (Linguistische Arbeiten 580). Berlin: de Gruyter.

Carlson, Greg. 1977. Reference to kinds in English. Amherst: University of Massachusetts dissertation.

Carlson, Greg \& Jeffrey Pelletier. 1995. The generic book. Chicago: University of Chicago Press.

Carlson, Gregory \& Rachel Sussman. 2005. Seemingly indefinite definites. In Stephan Kepser \& Marga Reis (eds.), Linguistic evidence: Empirical, theoretical, and computational perspectives, 71-85. Berlin: Mouton de Gruyter.

Casenave-Harigile, Junes. 2006. Xiberotar gramatika llaburra. Maule: Sü Azia.

Chierchia, Gennaro. 1998a. Plurality of mass nouns and the notion of 'semantic parameter'. In Susan Rothstein (ed.), Events and grammar, 53-103. Dordrecht: Kluwer.

Chierchia, Gennaro. 1998b. Reference to kind across languages. Natural Language Semantics 6. 339-405.

Chierchia, Gennaro. 2009. Mass nouns, vagueness and semantic variation. Synthese 174. 99-149.

Contreras, Heles. 1986. Spanish bare NPs and the ECP. In Ivonne Bordelois, Heles Contreras \& Karen Zagona (eds.), Generative studies in Spanish syntax, 25-49. Dordrecht: Foris.

Corbett, Greville. 2000. Number. Cambridge: CUP.

Coyos, Battittu. 1999. Le parler basque souletin des Arbailles: Une approche de l'ergativité. Paris: L'Harmattan.

Cyrino, Sonia \& M.Teresa Espinal. 2014. Bare nominal in Brazilian Portuguese: more on the DP/NP analysis. Natural Language and Linguistic Theory 33: 471-521.

Dayal, Veneeta. 2004. Number marking and (in)definiteness in kind terms. Linguistics \& Philosophy 27. 393-450.

Delfitto, Denis \& Jan Schroten 1991. Bare plurals and the number affix in DP. Probus 3(2). 155-186.

Dobrovie-Sorin, Carmen. 2009. Existential bare plurals: From properties back to entities. Lingua 119. 296-313.

Dobrovie-Sorin, Carmen. 2012. Number as a feature. In Laura Brugé, Anna Cardinaletti, Giuliana Giusti, Nicola Munaro \& Cecilia Poletto (eds.), Functional heads, 304-324. Oxford: Oxford University Press.

Dobrovie-Sorin, Carmen \& Brenda Laca. 2003. Les noms sans déterminant dans les langues romanes. In Danièle Godard (ed.), Les langues romanes. Problèmes de la phrase simple, 235-281. Paris: Editions du CNRS.

Dobrovie-Sorin, Carmen \& Claire Beyssade. 2012. Redefining indefinites. Dordrecht: Springer. Eguren, Luis. 2005. Marcas de predicación en vasco. In Beatriz Fernández \& Itziar Laka (eds.), Andolin gogoan: Essays in honour of Professor Eguzkitza, 233-250. Bilbao: UPV/EHU.

Eguren, Luis. 2006. Non-canonical uses of the article in Basque. Proceedings of the 32nd Annual Meeting of the Berkeley Linguistics Society (BLS), 111-122. Berkeley: University of California. 
Eguren, Luis. 2012. Predication markers in Basque. In Etxeberria, Urtzi, Ricardo Etxepare \& Myriam Uribe-Etxebarria (eds.), Noun phrases and nominalization in Basque: Syntax and semantics, 243-266. Amsterdam: John Benjamins.

Eguzkitza, Andolin. 1986. Topics in the syntax of Basque and Romance. Los Angeles: UCLA dissertation.

Espinal, M.Teresa. 2010. Bare nominals in Catalan and Spanish. Their structure and meaning. Lingua 120. 984-1009

Espinal, M.Teresa \& Louise McNally. 2007. Bare singular nominals and incorporating verbs. In Georg Kaiser and Manuel Leonetti (eds.), Proceedings of the 3rd Nereus Workshop, 45-62, Universität Konstanz Arbeitspapier 122.

Espinal, M.Teresa \& Louise McNally. 2011. Bare nominals and incorporating verbs in Spanish and Catalan. Journal of Linguistics 47(1). 87-128.

Etxebarne, Juje. 2006. Xiberotar gramatika, Maule: Sü Azia.

Etxeberria, Urtzi. 2005. Quantification and domain restriction in Basque. Bilbao: University of the Basque Country (UPV/EHU \& HiTT) dissertation.

Etxeberria, Urtzi. 2008. On quantification in Basque and on how some languages restrict their quantificational domain overtly. In Lisa Matthewson (ed.), Quantification: A crosslinguistic perspective, 225-276. London: Emerald.

Etxeberria, Urtzi. 2009. Contextually restricted quantification in Basque. In Anastasia Giannakidou \& Monika Rathert (eds.), QP structure, nominalizations, and the role of DP, 76-107. Oxford: Oxford University Press.

Etxeberria, Urtzi. 2010. Making a definite be interpreted as an indefinite. In Roberta Pires \& Carmen Dobrovie-Sorin (eds.), Journal of Portuguese Linguistics 9(1). 29-51.

Etxeberria, Urtzi. 2012. Quantification in Basque. In Ed Keenan \& Denis Paperno (eds.), Handbook of Quantifiers in Natural Languages, 183-164. Berlin: Springer.

Etxeberria, Urtzi. 2014. Basque nominal: from a system with bare nouns to a system without. In Ana Aguilar-Guevara, Bert Le Bruyn \& Joost Zwarts (eds.), Weak referentiality, 335-364. Amsterdam: John Benjamins.

Etxeberria, Urtzi. In preparation. Nominal expressions in Basque, Ms. CNRS-IKER.

Etxeberria, Urtzi \& Anastasia Giannakidou. 2009. Contextual domain restriction across languages: Definiteness, indefiniteness, and the structure of QP. Ms. CNRS-IKER \& Uiniversity of Chicago.

Etxeberria, Urtzi, Susagna Tubau, Joan Borras-Comes, Viviane Déprez \& M. Teresa Espinal. 2018. Relating (un)acceptability to interpretation. Experimental investigations on negation. Frontiers in Psychology 8: article 2370.

Etxeberria, Urtzi, Susagna Tubau, \& M. Teresa Espinal. 2021. Polarity items in Basque. Experimental evidence for the lack of negative concord. Natural Language and Linguistic Theory. DOI: https://doi.org/10.1007/s11049-021-09513-2.

Espinal, M. Teresa, Urtzi Etxeberria \& Susagna Tubau. In preparation. The limits between polarity licensing and negative concord: a reference to Basque in contrast to other languages.

Etxepare, Ricardo. 2003. Negation. In Jose Ignacio Hualde \& Jon Ortiz de Urbina, (eds.), A grammar of Basque, 387-421. Berlin: Mouton de Gruyter.

Euskaltzaindia. 1993. Euskal Gramatika Laburra: Perpaus Bakuna, Bilbao: Euskaltzaindia. Fara, Delia G. 2001. Descriptions as Predicates. Philosophical Studies 102. 1-42.

Farkas, Donka. 1998. Dependent indefinites. In Francis Corblin, Danièle Goddard \& Jean-Marie Marandin (eds.) Empirical issues in formal syntax and semantics, 243-267. Frankfurt: Peter Lang. 
Fintel, Kai von. 2000. Whatever. In Brendan Jackson \& Tanya Matthews (eds.), Proceedings of SALT 10, 27-40. Ithaca, NY: Cornell University.

van Geenhoven, Veerle. 1998. Semantic incorporation and indefinite descriptions: Semantic and syntactic aspects of noun incorporation in West Greenlandic. Stanford. CA: CSLI Publications.

Giannakidou, Anastasia. 1997. Linking sensitivity to limited distribution: the case of free choice. In Paul Dekker, Martin Stokhof \& Yde Venema (eds.), Proceedings of the 11th Amsterdam Colloquium, 139-145. Amsterdam: ILLC, University of Amsterdam.

Giannakidou, Anastasia. 1998. Polarity sensitivity as (non)veridical dependency. Amsterdam \& Philadelphia: John Benjamins.

Giannakidou, Anastasia. 2000. Negative ... concord? Natural Language and Linguistic Theory 18. 457-523.

Giannakidou, Anastasia. 2001. The meaning of free choice. Linguistics and Philosophy 24. 659-735.

Giannakidou, Anastasia. 2006. N-words and negative concord. In Martin Everaert, Henk van Riemsdijk, Rob Goedemans \& Bart Hollebrandse (eds.), The Blackwell companion to syntax, 327-392. Malden, MA: Blackwell.

Giannakidou, Anastasia. 2011. Positive polarity items and negative polarity items: variation, licensing, and compositionality. In Claudia Maienborn, Klaus von Heusinger \& Paul Portner (eds.), Semantics: An international handbook of natural language meaning (2nd edn), 1660-1712. Berlin: de Gruyter.

Giannakidou, Anastasia. 2017. Polarity in the semantics of natural language. In Oxford research encyclopedia of Linguistics. https://doi.org/10.1093/acrefore/9780199384655.013.7

Giannakidou, Anastasia \& Josep Quer. 2013. Exhaustive and non-exhaustive variation with anti-specific indefinites: free choice versus referential vagueness. Lingua 126. 120-149.

Giannakidou, Anastasia \& Suwon Yoon. 2016. Scalar marking without scalar meaning: Non-scalar, non-exhaustive even-marked NPIs in Greek and Korean. Language 92(3). 522-556.

Giusti, Giuliana. 2021, this volume. Partitivity in Italian: A protocol approach to a multifaceted phenomenon. In Petra Sleeman \& Giuliana Giusti (eds.), Partitive determiners, partitive pronouns and partitive case (Linguistische Arbeiten 580). Berlin: de Gruyter.

Giusti, Giuliana \& Petra Sleeman. 2021, this volume. Partitive elements in the languages of Europe. An advancement in the understanding of a multifaceted phenomenon. In Petra Sleeman \& Giuliana Giusti (eds.), Partitive determiners, partitive pronouns and partitive case (Linguistische Arbeiten 580). Berlin: de Gruyter.

Goenaga, Patxi. 1980. Gramatika bideetan. Donostia: Erein.

Goenaga, Patxi. 1991. Izen sintagmaren egituraz. In Joseba Lakarra (ed.), Memoriae L. Mitxelena magistri sacrum, 847-865. Donostia: EHU.

Görgülü, Emrah. 2018. Nominals and number neutrality in languages. Language and Linguistics Compass 12. https://doi.org/10.1111/lnc3.12301

Haspelmath, Martin. 1997. Indefinite pronouns. (Oxford Studies in Typology and Linguistic Theory). Oxford: Oxford University Press.

Henderson, Robert. 2014. Dependent indefinites and their post-suppositions. Semantics and Pragmatics 7. Article 6.1-58.

Heusinger, Klaus von \& Jaklin Kornfilt, 2021, this volume. Turkish partitive constructions and (non-)exhaustivity. In Petra Sleeman \& Giuliana Giusti (eds.), Partitive determiners, partitive pronouns and partitive case (Linguistische Arbeiten 580). Berlin: de Gruyter. 
Hoeksema, Jack. 2012. On the natural history of negative polarity items. Linguistic Analysis 38(1-2). 3-34.

Huumo, Tuomas. 2021, this volume. Longitudinal or transverse? How the unbounded quantity expressed by the Finnish partitive case relates to time. In Petra Sleeman \& Giuliana Giusti (eds.), Partitive determiners, partitive pronouns and partitive case (Linguistische Arbeiten 580). Berlin: de Gruyter.

Irigoien, Alfonso. 1985. Euskarako izen sintagma mugatzailerik gabekoez. Euskera XXX. 129-139. Irurtzun, Aritz. 2006. Focus and clause structuration in the minimalist program. In Cedrick Boeckx (ed.), Minimalist essays, 68-96. Amsterdam: Benjamins.

Irurtzun, Aritz. 2016. Strategies for argument and adjunct focalization in Basque. In Beatriz Fernández \& Jon Ortiz de Urbina (eds.), Microparameters in the grammar of Basque, 243-263. Amsterdam: Benjamins.

Jespersen, Otto. 1924. The philosophy of grammar. London: Allen \& Unwin.

Karlsson, Fred. 1983. Finnish Grammar. Porvoo, Helsinki, Juva: Werner Söderström Osakeyhtiö.

Kleiber, Georges. 1990. L'article LE générique. La généricité sur le mode massif. Genève-Paris: Droz.

Kratzer, Angelika \& Junko Shimoyama. 2002. Indeterminate pronouns: the view from Japanese. In Yukio Otsu (ed.), Proceedings of the 3rd Tokyo Conference on Psycholinguistics, 1-25. Tokyo: Hituzi Syobo.

Krifka, Manfred, Francis J. Pelletier, Gregory N. Carlson, Alice ter Meulen, Gennaro Chierchia \& Godehard Link. 1995. Genericity: An introduction. In Gregory N. Carlson \& Francis J. Pelletier (eds.), 1-124. The generic book. Chicago: University of Chicago Press.

Laakso, Johanna. 2001. The Finnic languages. In Östen Dahl \& Maria Koptjevskaja-Tamm (eds.), The Circum-Baltic languages: Typology and contact, vol. 1, 179-212. Amsterdam: John Benjamins.

Lafitte, Piarres. 1944. Grammaire basque (navarro-labourind littéraire), $2^{\text {nd }}$ edn Bayonne: Amis du Musée Basque, 1962. (Repr. Donostia-San Sebastían: Elkar, 1979).

Laka, Itziar. 1990. Negation in syntax: On the nature of functional categories and projections. Cambridge, MA: MIT dissertation.

Laka, Itziar. 1993. Unergatives that assign ergative, unaccusative that assign accusative. In Jonathan Bobaljik \& Phillips Collin (eds.), MIT Working Papers in Linguistics 18 (Papers on Case and Agreement I). 149-172.

Larramendi, Martin. 1729. El impossible vencido. Arte de la lengua bascongada. Salamanca. A. J. Villagorde Alcaráz.

Lazaridou-Chatzigoga, Dimitra, Napoleon Katsos \& Linnaea Stockall. 2016. The effect of context on generic and quantificational statements. In Fabienne Salfner \& Uli Sauerland (eds.), Pre-proceedings of trends in experimental pragmatics, 87-94. Berlin: XPRAG.de.

Lécluse, Fleury. 1826. Manuel de la langue basque. Bayonne: L. M. Cluzeau.

Longobardi, Giuseppe. 1994. Reference and proper names: A theory of N-movement in syntax and logical form. Linguistic Inquiry 25(4). 609-665.

Longobardi, Giuseppe. 2001. The structure of DPs: some principles, parameters, and problems. In Mark Baltin \& Chris Collins (eds.), The handbook of contemporary synactic theory, 562-603. Oxford: Blackwell.

Manterola, Julen. 2006. -a euskal artikulu definituaren gainean zenbait ohar. In Joseba A. Lakarra \& José I. Hualde (eds.), Studies in Basque and historical linguistics in memory of R.L. Trask - R.L. Trasken oroitzapenetan ikerketak euskalaritzaz eta hizkuntzalaritza historikoaz, 651-676. Donostia-Bilbo: Gipuzkoako Foru Aldundia-EHU. (Supplements of ASJU). 
Manterola, Julen. 2008. -a morfemaren erabilera (eza) ekialdeko euskaretan. In Joseba Andoni Lakarra, Joaquín Gorrotxategi \& Blanca Urgell (eds.), Proceedings of 2nd conference of the Luis Michelena Chair, 71-95. Vitoria-Gasteiz: University of the Basque Country Editorial Service.

Manterola, Julen. 2009. - $a$ and bat Basque articles and recent contact theories. - $\mathrm{a}$ and bat Basque articles and recent contact theories. Paper presented at the workshop Language contact and morphosyntactic variation and change, September 2007, Paris, France. https://artxiker.ccsd.cnrs.fr/artxibo-00350278/document

Manterola, Julen. 2012. Synchronic ubiquity of the Basque article -a: A look from diachrony. In Urtzi Etxeberria, Ricardo Etxepare \& Myriam Uribe-Etxebarria (eds.), Noun phrases and nominalizations in Basque: Syntax and semantics, 179-208. Amsterdam: John Benjamins.

Manterola, Julen. 2015. Euskararen morfologia historikorako: artikuluak eta erakusleak. UPV/EHU dissertation.

Michelena, Luis. 1964. Sobre el pasado de la lengua vasca. Donostia: Auñamendi.

Michelena, Luis. 1987. Palabras y textos. Bilbao: UPV/EHU.

Munn, Alan \& Christina Schmitt. 2005. Number and indefinites. Lingua 115. 821-855.

Oihenart, Arnaut. 1638. Notitia utriusque Vasconiae. Paris: Cramoisy.

Ortiz de Urbina, Jon. 1983. Empty categories and focus in Basque. Studies in the Linguistics Sciences 13(1). 133-156.

Ortiz de Urbina, Jon. 1989. Parameters in the grammar of Basque. Dordrecht: Foris.

Ortiz de Urbina, Jon. 1999. Focus in Basque. In George Rebuschi \& Lorie Tuller (eds.), The grammar of focus, 311-333. Amsterdam: John Benjamins.

Paykin, Katia \& Marleen van Petegehem. 2002. Definiteness in a language without articles: A case-study of Russian. Recherches linguistiques de Vincennes 31: 97-112.

Pereltsvaig, Asya. 2008. Russian nibud'-series as markers of co-variation. In Natasha Abner \& John Bishop (eds.), Proceedings of the West Coast Conference on Formal Linguistics (WCCFL) 27, 370-378. Somerville, MA: Cascadilla Press.

Perlmutter, David M. 1978. Impersonal passives and the Unaccusative Hypothesis. In Proceedings of the fourth Annual Meeting of the Berkeley Linguistics Society, 157-189.

Rijk, Rudolf P. G. de. 1972. Partitive assignment in Basque. ASJU 6: 130-173. [Reprinted in de Rijk 1998].

Rijk, Rudolf P. G. de. 1996. On the origin of the partitive determiner. ASJU 30 [Reprinted in de Rijk 1998].

Rijk, Rudolf P. G. de. 1998. De lingua vasconum: Selected writings. EHU. (Supplements of ASJU 43).

Rodriguez, Sonia. 2003. Euskal artikuluaren sintaxiaz. Ms. UPV/EHU.

Rullmann, Hotze \& Aili You. 2006. General number and the semantics and pragmatics of indefinite bare nouns in Mandarin Chinese. In Klaus von Heusinger \& Ken P. Turner (eds.), Where semantics meets pragmatics, 175-196. Amsterdam: Elsevier.

Seržant, Ilja. 2021, this volume. Diachronic typology of partitives. In Petra Sleeman \& Giuliana Giusti (eds.), Partitive determiners, partitive pronouns and partitive case (Linguistische Arbeiten 580). Berlin: de Gruyter.

Swart, Henriette de, Yoad Winter \& Joost Zwarts. 2007. Bare nominals and reference capacities. Natural Language and Linguistic Theory, 25(1). 195-222

Timberlake, Alan. 1977. Reanalysis and actualization in syntactic change. In Charles N. Li (ed.), Mechanisms of syntactic change, 141-177. Austin: University of Texas Press. 
Trask, Larry. 2003. The noun phrase: Nouns, determiners, and modifiers; pronouns and names. In José I. Hualde, \& Jon Ortiz de Urbina (eds.), A grammar of Basque, 92-134. Dordrecht: Kluwer.

Txillardegi. 1977. L'emploi de l'indéfini en souletin. Fontes Linguae Vasconum 25. 29-54.

Uriagereka, Juan. 1999. Minimal restriction on Basque movements. Natural Language and Linguistic Theory 17. 403-444.

Uribe-Etxebarria, Myriam. 1992. On the structural position of the subject in Spanish, their nature and their consequences for quantification. Syntactic Theory and Basque Syntax; Supplements of the International Journal of Basque Linguistics and Philology XXVII. 447-493.

Wilhelm, Andrea. 2008. Bare nouns and number in Dene Suline. Natural Language Semantics 16. 39-68.

Wouden, Ton van der. 1994. Polarity and 'illogical negation'. In Makoto Kanazawa \& Christopher J. Pinon (eds.), Dynamics, polarity and quantification, 17-45. Stanford, CA: CSLI.

Zabala, Igone. 1993. Predikazioaren teoriak gramatika sortzailean. Bilbao: UPV/EHU dissertation.

Zabala, Igone. 2003. Nominal predication: copulative sentences and secondary predication. In José I. Hualde \& Jon Ortiz de Urbina (eds.), A grammar of Basque, 324-339. Dordrecht: Kluwer.

Zamparelli, Roberto. 1998. A Theory of Kinds, Partitives and Of/Z Possessives. In Artemis Alexiadou, \& Christopher Wilder (eds.), Possessors, predicates and movement in the Determiner Phrase, 259-304. Amsterdam: John Benjamins.

Zwarts, Frans. 1981. Negatief polaire uitdrukkingen I. GLOT 4(1). 35-133.

Zwarts, Frans. 1995. Nonveridical contexts. Linguistic Analysis 25. 286-312.

Zwarts, Frans. 1998. Three types of polarity items. In Fritz Hamm \& Erhard W. Hinrichs (eds.), Plurality and quantification, 177-238. Dordrecht: Kluwer. 
